\title{
Postimperial Indifference, Fragmentation, and Nostalgia in Costumbrismo.
}

Joseba Gabilondo

Michigan State University

joseba@msu.edu

\begin{abstract}
This article analyzes costumbrismo as the first literary genre to develop the notion of postimperial nostalgia in nineteenth-century Spain. The article argues that a postimperialist analysis of this literature can shed light on the rather, idiosyncratic history of nineteenth-century Spanish literature (literature of manners and historical novel > almost no realism > naturalism). It also establishes the bases for a more cultural and political understanding of nostalgia and modernity in Spain and the Hispanic Atlantic as well as the (postmodern) Global North, so that Spanish nationalism is redefined as an (indifferent) postimperial discourse about colonial loss. More theoretically, the article aims at redefining nineteenth-century Spanish history in Lacanian terms by arguing that Spain as a nation is simply an imaginary formation of a symbolic
\end{abstract}


order that is ultimately Atlantic and post/imperial, wherein the colonial loss points to the traumatic irruption of the Real.

Keywords: costumbrismo or literature of manners; nostalgia; nineteenthcentury Spain; symbolic/imaginary; Hispanic Atlantic; postimperialism; fragmentation; colonial loss.

\section{Resumen}

Este artículo analiza el género discursivo que cifra por primera vez la nostalgia postimperial en la España del siglo XIX: el costumbrismo o literatura de costumbres. El artículo sostiene que un análisis postimperialista de esta literatura puede arrojar luz sobre la historia más bien idiosincrática de la literatura española del siglo XIX (literatura de costumbres y novela histórica > casi ausencia completa de realismo > naturalismo). También establece las bases para una comprensión más cultural y política de la nostalgia y la modernidad en España y en el Atlántico hispano, así como en el Norte Global (posmoderno), de tal manera que el nacionalismo español se redefine como un discurso (indiferente) postimperial de la pérdida colonial. Más teóricamente, el artículo redefine la historia española del siglo XIX en términos lacanianos argumentando que España como nación es simplemente una formación imaginaria de un orden simbólico que es en última instancia atlántico y post/imperial y donde la pérdida colonial apunta a la irrupción traumática del Real.

Palabras clave: costumbrismo; nostalgia; España; siglo XIX; orden simbólico/ imaginario; Atlántico hispánico; postimperialismo; fragmentación; pérdida colonial. 


\section{The Atlantic and the Imperialist Economy of Loss and Gain}

This article focuses on the early nineteenth century in order to explain an apparent contradiction on the Spanish discourse of colonial loss. Although most colonies were lost early in the century (1810-1825), for much of the remainder of the century, Spain displayed what I identify as a rhetoric of postimperial indifference. The term 'postimperial' will be used here to refer to Spanish history immediately after the loss of the majority of its colonies in the early nineteenth century-although technically Spain became fully postimperial in 1898. However, when the transoceanic colonial remainder of the Spanish empire (Cuba, Puerto Rico, the Philippines, and Guam) was lost at the end of the nineteenth century (1898), the discourse of loss escalated from indifference to national outcry (the Disaster) and an entire generation of intellectuals (the Generation of 98) was mobilized to analyze this loss, thus generating a new discourse of nostalgia and melancholia, most clearly articulated by Unamuno. Given the precedent set by the limited success of the war against Morocco in 1859-1860, curtailed by Britain, Spain's possessions in Africa were not considered symbolically and politically as important as its transoceanic ones. Only after the Rif War (1920-1927) did Spain turn back its imperial imagination to Africa. Colonies such as Equatorial Guinea were neglected in the nineteenth century and only became important later in the twentieth due to the cocoa trade. The Spanish Imperialist imagination of the nineteenth century was eminently transoceanic.

The analysis of this apparent contradiction in the different Spanish responses to colonial loss at the beginning and at the end of the nineteenth century is not simply an academic oversight that must be corrected. This "correction" cannot be conducted so that, then, we can revert to an already established metanarrative of Spanish postimperialist history: Spain lost all its colonies throughout the nineteenth century (1812-1898), but, despite of this loss, it managed to emerge as a new nation (1898-). 
In contrast to that standard narrative this article aims to identify the original "postimperial indifference" of the early nineteenth century as a site from which the Atlantic history of Spain in that century can be re-read against the nationalist grain. By mobilizing psychoanalysis, feminism, postcolonial theory, and Marxism and by analyzing "postimperial indifference," I want to argue that nineteenth-century Spanish history cannot be read as a national history in which a Spanish political subject loses and gains, according to different imperialist changes in Atlantic history (colonial loss). Rather, it has to be read as a postimperial history of fragmentation in which nationalism becomes an imaginary and discursive enplotment that unsuccessfully attempts to contain and suture the declining Spanish empire and its inevitable fragmentation.

"Postimperial indifference" leads us to an alternative theorization of Spanish history: Spain not as a nation-a unified cultural and political subject-defined by colonial loss and national gain, but instead a fragmenting, decaying empire. Spain can be seen then as an empire that attempts to solve its fragmentation by recurring unsuccessfully to a national organization of culture and politics. We could thus redefine nineteenth-century Spanish history in more Lacanian terms by arguing that Spain as a nation is simply an imaginary formation of a symbolic order that is ultimately Atlantic and post/imperialist and where colonial loss points to the traumatic violent irruption of the Real. In short, Spain is the national imaginary of an imperialist Atlantic symbolic order whose Real is colonial loss.

Although this formulation has also implications for Latin America, I will concentrate here on the Spanish case. Ultimately, I am attempting to formulate the bases for an archaeology of a Hispanic Atlantic Symbolic Order, which has never been national but always tied to the imperial/colonial project. Spain as an imaginary national subject is simply a postimperialist element or signifier of a symbolic order that, until the nineteenth century, was imperial-colonial and thereafter postimperial-colonial. Thus, symbolically speaking, Spain must be 
retheorized as a national imaginary subject of a postimperial-colonial Atlantic symbolic order. The implications of a new understanding of a postimperial Spain for contemporary history exceed the limits of this article. Here, I will only set the basis-the archaeology — that permits to explore such implications.

Alongside the above geopolitical and psychoanalytical argument of postimperialism, I want to concentrate on the specific form in which the Spanish economy of (colonial) loss and (national) gain is articulated: nostalgia. From the early nineteenth century until contemporary times, nostalgia is the prevalent discursive form deployed by Spanish culture to articulate itself as a national subject. As I will elaborate here, nostalgia is an intricate formation that has a more complex history than the dismissive simplification perpetuated since José Montesinos's criticism of costumbrismo or literature of manners as nostalgic discourse.

Moreover, nostalgia is a new discursive mode that has gained prevalence in societies of the Global North with globalization (postmodernism). Therefore, I also want to problematize the relationship between nostalgia-as post/ imperialist loss and gain-and the shift from modernity to globalization (postmodernity). Following Gilroy's argument that the first modern subject is the (Atlantic) slave and his/her double consciousness, I want to argue here that the first hegemonic imperialist subject of modernity is Hispanic, since modern (colonial) loss and double consciousness-rather than newness and gain-are experienced by the Hispanic postimperial field (Spain) in a way that only the subject of the Global North is experiencing in globalization (postmodernity). Fredric Jameson argues that:

At any rate, from this nostalgic and regressive perspective-that of the older modern and its temporalities-what is mourned is the memory of deep memory; what is enacted is a nostalgia for nostalgia, for the grand older extinct questions of origin and telos, of deep time and the Freudian Unconscious (dispatched by Foucault at one blow in the History of Sexuality), for the dialectic 
also, as well as all the monumental forms left high and dry by the ebb tide of the modern moment, forms whose Absolutes are no longer audible to us, illegible hieroglyphs of the demiurgic within the technocratic world.

We need a detour through the modern, then, in order to grasp what is historically original in the postmodern and its spatialisms. Indeed, such a history lesson is the best cure for nostalgic pathos, minimally teaching us, by way of Necessity, that the way back to the modern is sealed for good. (156)

In the Spanish case, postimperial nostalgia, deployed since the early nineteenth century, is indeed nostalgia for Spanish modernity, originating in the Golden Age at the height of Spanish imperialist expansion. Therefore, an anamnesis of Spanish nostalgia reverses the modern/global (postmodern) debate on nostalgia, temporality, and memory. The equation of modernity with deep history and memory, on the one hand, and of globalization/postmodernity with flatness and nostalgia, on the other, must be revised on the light of nineteenth-century postimperial Spanish nostalgia originally formulated by costumbrismo.

In order to discuss the above formations, this article will focus more specifically on the discursive genre that analyzes for the first time postimperial nostalgia in nineteenth-century Spain: costumbrismo or literature of manners and customs. It is my contention that a postimperialist analysis of this literature can shed light on the rather idiosyncratic periodization of nineteenth-century Spanish literature to this day: literature of manners and historical novel > almost no realism > naturalism. At the same time, this analysis might also establish the bases for a more cultural and political understanding of nostalgia and modernity in Spain and the Hispanic Atlantic as well as the global/postmodern Global North. 


\section{Postimperial Indifference}

As stated above, Spain entered modernity at the beginning of the nineteenth century through a discourse of loss: the Napoleonic invasion threatened the liquidation of Spain as a sovereign territory while the subsequent colonial wars of independence in Latin America once again pushed the Spanish empire to the brink of imperialist non-existence. Internally, the Carlist civil wars as well as countless military coups and popular uprisings had a similar effect of fragmentation and loss in the economic, political, and cultural body of the Spanish empire. Thus, Spain emerged by mid-nineteenth-century as a country at a loss, as a fragmented empire falling apart. In the meantime, Spain only slowly recognized the Latin American postcolonial republics, starting with Mexico in 1836 and ending with Honduras in 1894 (Suárez Fernández 151).

As historian Raymond Carr argues, the incidents of the first third of the nineteenth century are not disconnected from more recent Spanish history. There is a historical continuity reflected in the naming of these conflicts: "by the end of 1822, what has been called the first Spanish Civil War had begun" (137). That is, the first political incidents during the post-Napoleonic Restoration of Fernando VII (1814-33) were only the beginning of a series of wars that culminated in the twentieth century with the last Civil War of 193639.

Furthermore, the above incidents establish a political modus, a political logic, that defines nineteenth- and twentieth-century Spanish history. As Carr continues, "1820 [the year of General Riego's revolutionary uprising] set the procedures of liberal revolution: an army revolt, backed by a provincial rising and finally sanctioned by a change of course in Madrid. This was 'the Spanish method of making a revolution' repeated in 1854 and 1868" (129). This political 
logic is also at the core of the emancipation of the Latin American colonies. As Carr concludes: "The Revolution of Riego was not merely a crise de conscience for Spain and Europe; it was a decisive event across the Atlantic, in that it finally assured the creation of the independent Republics of Latin America" (143).

In the mist of all these incidents, the Spanish response to colonial emancipation was not one of outcry or rage, but rather one of indifference, postimperial indifference. When I use the term "indifference" here, I am also trying to encompass the etymological meaning of the word: Spain does not differentiate itself from its ex-colonies. In a process that lasted sixty years, Spain went back and forth between disavowal, negation, dismissal, reconciliation, desire, etc. in a relationship that can only be described as abject (Kristeva), that is, one in which the symbolic and political order that establishes difference collapses. As Carr summarizes:

For many years official Spain refused to recognize it had lost America; it cherished illusions of a military come-back in Peru, of a 'spontaneous' return of a continent exhausted by the anarchy of independence. Hence the refusal to recognize the new nations: pressure for reconciliation came from a desire to reopen trade (which had ceased since 1824) and to preserve as Spanish possessions the only remnants of the Empire-Cuba and Puerto Rico. Hence the spread of the belief that emancipation had been inevitable and that Spain should not nurse her resentment at a 'premature separation.' Recognition, nevertheless, took sixty years in all. (145-46, my emphasis)

This postimperialist indifference is even more pronounced and surprising if contemporary historical accounts of Spanish history and culture written in the genre of costumbrismo in the first half of the nineteenth century are taken into consideration. Esteban Mesonero Romanos, probably the most canonical author of this type of literature, along with Mariano José de Larra 
and Serafín Estébanez Calderón, does not refer to colonial emancipation when revising Spanish history. In his article "Las costumbres de Madrid" (1832), later compiled in his Escenas y tipos matritenses (1851), Mesonero Romanos does not even mention colonial loss when dealing with recent Spanish history. It is important to bear in mind that the process of colonial emancipation ended just eight years earlier, in 1824 with the Battle of Ayacucho. Mesonero Romanos recenters Spanish history alongside the axis of modernity and North-European (especially French) imperialist influence:

El transcurso del tiempo y los notables sucesos que han mediado desde los últimos años del siglo anterior, han dado a las costumbres de los pueblos nuevas direcciones [...]. Los españoles, aunque más afectos en general a los antiguos, no hemos podido menos de participar de esta metamorfosis, que se hace sentir tanto más en la corte por la facilidad de las comunicaciones y el trato con los extranjeros. Añádanse a estas causas las [French] invasiones repetidas dos veces este siglo, la mayor frecuencia de los viajes exteriores, el conocimiento muy generalizado de la lengua y la literatura francesas, el entusiasmo por sus modas, y más que todo, la falta de una educación sólidamente española, y se conocerá la necesidad de que nuestras costumbres hayan tomado un carácter galo-hispano, peculiar del siglo actual, y que no han trazado ni pudieron prever los rígidos moralistas, o los festivos críticos que describieron a España en los siglos anteriores. (122-23, my emphasis)

A similar historical narrative can be observed in Larra's work. Articles such as "La noche buena de 1836. Yo y mi criado. Delirio filosófico" (1836) and "El casarse pronto y mal” (1832) ignore colonial loss-Estébanez Calderón does not provide similar historical accounts. Larra is very aware of the peripheral location of Spain in modernity. He delineates a position at a loss, defined by an ongoing fragmentation and violence that even Spaniards have internalized. Once again, in this new repositioning of Spain, colonial loss is not acknowledged, only the new logic of French and north European modernity. 
In his 1833 article "En este país," for example, Larra reflects on the derogatory use of the expression of the title, and at the same time, attempts to create a critical space, a situated discourse, that can counteract European modernity:

Olvidemos, lo repetimos, esa funesta expresión [En este país] que contribuye a aumentar la injusta desconfianza que de nuestras propias fuerzas tenemos. Hagamos más favor o justicia a nuestro país, y creámosle capaz de esfuerzos y felicidades. Cumpla cada español con sus deberes de buen patricio y, en vez de alimentar nuestra inacción con la expresión de desaliento: “iCosas de España!”, contribuya cada cual a las mejoras posibles. Entonces este país dejará de ser tan maltratado de los extranjeros, a cuyo desprecio nada podemos oponer, si de él les damos nosotros mismos el vergonzoso ejemplo. (78)

Estébanez Calderón too deploys a similar location when he claims that "Yo [...] tengo ciega pasión por todo cuanto huele a España” (9). In his article El Roue y el bronquis, he comments on some famous water-springs and adds that:

Ello es, que además de tanto viajante y peregrino español castizo, se dejan ver por allí no pocos gringos y extranjeros que encontrándose por ventura en Cádiz, Málaga o Gibraltar, y oyendo hablar de los nombrados baños, quieren, visitándolos, aprovechar la buena ocasión de conocer mejor el país, amén de adornar su álbum con algún pintarrajo tomado al través, y pintado con brocha, y de enriquecer sus apuntes y recuerdos de viaje con algún mentirón estupendo, que después se revela en lindo periódico o keepsek [sic] de impresión de París y Londres, haciendo arquear los ojos de aquellos buenos leyentes, y provocándonos a nosotros a risa estrepitosa de regocijo, si no ya de mofa y desprecio. (77-8)

As Carr argues, the influence of north European, and especially French, modernity does not derive only from the impact of the Enlightenment and its ideas in the eighteenth century, it also represents an ongoing invasion, which 
after the 1840s, becomes also economic: "That so much of the energy for expansion had come from Paris meant that Spain was in danger of becoming an economic dependency of France; the Péreire brothers and the Rothschilds looked as if they might accomplish by their capital what Napoleon I had failed to accomplish by his arms" (271).

In this context, the Spanish postimperialist indifference towards the loss of its colonies points to a double reality: an ongoing fragmentation of the political imperialist body which is further aggravated by the cultural and economic influence of French and north European modernity. It would appear that the writers of the time could simply not deal with colonial loss; their interest was very much focused on the new modern reality, which threatened to turn Spain into a new colony of northern Europe. Spain had started to occupy a subaltern position vis-à-vis France and Britain, reminiscent of the location occupied by the Latin American colonies to that point. In other words, there is not a politically defined, stable position from which Spanish politicians and writers can reflect on colonial loss. Colonial loss is simply one more chapter in an ongoing process of decadence and fragmentation that requires focusing on a newer development: the cultural and economic invasion of modern Europe.

Costumbrismo or literature of manners is central to understanding this context. Unlike later developments - and against what traditional criticism has established after José Montesinos's work-early Spanish literature of manners is not temporarily structured so that Spanish imperialist history can be narrated as a discourse of loss. The type of literature of manners written in the late 1820 s and 1830 s is not nostalgic. Rather, it is spatially structured so that the influence of European modernity and its internalized effects in Spanish politics and culture can be counteracted. Montesinos claims:

cada vez que vemos aparecer un costumbrista consciente de su obra, oiremos de su boca la afirmación del mismo propósito: dar fe de un cambio, de una revolución, de una evolución que ha transformado la faz de todo el país o de 
alguno de sus rincones pintorescos, y desahogar, entregándose al recuerdo, la nostalgia de todo lo desaparecido y olvidado. (44, my emphasis)

The earlier corpus of costumbrista writing, however, does not fit well within Montesinos's description. The above quotes by Mesonero Romanos, Larra, and Estébanez Calderón point to the fact that, even when the invasion of European modernity is acknowledged on its historicity, its effects are not organized alongside a nostalgic temporal axis. Rather, they are deployed alongside a spatial or geopolitical axis so that they are counteracted or neutralized. Montesinos appears to be aware of the contradiction in which most costumbrista writers are caught, but he dismisses them for their inability to counteract the new, the present, i.e. modernity: "Todo el costumbrismo español parece nacido de una crisis de nacionalidad, y sentimentalmente, la simpatía de los autores se vuelve hacia el pasado, pero el presente los arrolla." (32) Had nostalgia been the main discursive mode of Spanish literature of manners, the colonial reality would have been the first and most important object of representation: the colonies represent the main loss experienced by the Spanish empire.

Mesonero Romanos, among others, was fully aware that the nostalgic glorification of disappearing traditional types of Spanish society was a narrative practice prevalent among foreign travelers rather than among Spanish writers. As early as 1832, in his "Las costumbres de Madrid," Mesonero Romanos denounced this practice on the part of north European writers:

Y es asi como en muchas obras publicadas en el extranjero de algunos años a esta parte con los pomposos títulos de La España, Madrid o las costumbres españolas, El Español, Viaje a España, etc. etc., se ha presentado a los jóvenes de Madrid enamorando con la guitarra; a las mujeres asesinando por celos a sus amantes; a las señoritas bailando el bolero; al trabajador descansando de no hacer nada; así es como se ha hecho de un sereno un héroe de novela; de un 
salteador de caminos un Gil Blas; de una manola de Lavapiés una amazona; de este modo se ha embellecido la plazuela de Afligidos, la venta del Espíritu Santo, los barberos, el coche de colleras y los romances de los ciegos, dándoles un aire a lo Walter Scott, al mismo tiempo que se deprimen nuestros más notables monumentos, las obras más estimadas del arte; y así en fin los más sagrados deberes, la religiosidad, el valor, la amistad, la franqueza, el amor constante, han sido puestos en ridículo y presentados como obstinación, preocupaciones, necedad y pobreza de espíritu. (124-26, my emphasis)

What Montesinos identified as the core practice of the literature of manners had already been understood and denounced as European romanticism by Mesonero Romanos in his early writings. In short, costumbrismo began as a politically situated cultural practice that aimed at counteracting and resisting the northern imperialistic effects of romanticism and modernity over an exoticized and backward European South.

In this context, the acknowledgment of colonial loss would represent a way to further aggravate the processes of postimperial fragmentation and displacement. Only by disavowing colonial loss, by being indifferent to it, and by attempting to reinsert continental Spain within the framework of European modernity could these writers resist imperialist loss and fragmentation while, at the same time, creating a postimperial Spanish location that could serve as a space from which to counteract European modernity. In short, costumbrismo and, thus, the Spanish cultural imagination of the early nineteenth century could not afford to mourn or nostalgically reflect on colonial loss. Their interest lied instead in counteracting the ongoing imperialist fragmentation, which was further accentuated not by the ex-colonies but rather by northern Europe.

As I will discuss later on, only in the 1850 s and 1860 s did, at last, a rising bourgeoisie attempt to become the new subject of Spanish postimperial nationalism, and only then did costumbrismo finally turn its gaze towards other Spanish regions and to Latin America to describe them through a form of 
colonial nostalgia. There is, then, in Spain long period defined by postimperial indifference, a 30- to 40-year lag between the actual loss of its colonies and their re-emergence in nostalgic representations. It is the historical analysis of this lag, as well as the nostalgic representation that came after it, that interests us here.

\section{Literature of Manners or Customs}

Originating at the end of the eighteenth century (Montgomery), the main narrative literary genre that consolidated in the aftermath of the Napoleonic invasion of Spain and of the ensuing Latin-American wars of independence is known as costumbrismo. Although the term costumbrismo could be translated, and I will translate it, as "literature of manners," or in French, littérature de moeurs, its Spanish strand presents a very characteristic configuration that so far, and with few exceptions (Coffey), has not been analyzed under a postimperial light. Literature of manners developed at the same time, during the 1820s and 1830s, in England, France, and Spain by such different authors as Hunt, Thackeray (even Dickens's Sketches by Boz and The Pickwick Papers), Jouy, Balzac (in his Physiologies), Mesonero Romanos, Larra, and Estébanez Calderón (Rubio Cremades "Costumbrismo;" Losada). Even the successful Los españoles pintados por sí mismos (1843) follows earlier French (Les français peints par eux-mêmes, 1839-1842) and English (Heads of the people, 1838) models. In the British and French cases, these portrayals of everyday-life urban customs led to the rise of the realist novel (Dickens and Balzac). This early form constitutes the first evidence of the effects of modernization and industrialization in modern European capitalist countries. This literature represents the alienation, exploitation, and decadence resulting from capitalist expansion. In other words, European literature of manners as it morphed into realism, represented history in its modern and reifying effects. It is a literature about history, modernity, and capitalism. 
As George Lukács reflects on Balzac's later work The Human Comedy (182947), he emphasizes the connection between realism, capitalism, and the ascendancy of the bourgeoisie:

he understood the peculiarities in the development of all classes of society in France since the revolution of 1789 . But such a statement would be incomplete if it disregarded the other side of the dialectic of class evolution, i.e., the continuity of the evolutionary trends from the French revolution onwards, or rather from the emergence of a bourgeois class in France and the beginning of the struggle between feudalism and absolute monarchy. The deep comprehension of this continuity of development was the foundation on which the great edifice of the Human Comedy was built. Revolution, Empire, restoration and July monarchy were in Balzac's eyes merely stages in the great, continuous and contradictory process of French evolution towards capitalism, a process in which the irresistible and the atrocious are inseparably linked together. [...] Balzac pursues this theme of the historical continuity of capitalist development in his portrayal of every class of French society. (40-1)

The above lengthy quote from Lukács helps us understand the fact that the emergence of a bourgeois class, capitalism, and literary realism are historically interconnected in such a way that literary realism becomes the modern representation of this history-precisely a narrative form whose origins are in the literature of manners (and the historical novel).

In the Spanish case, where the effects of French (and British) capitalism are being felt as a form of internal European colonialism-from romantic orientalization to economic investment and exploitation-in a decaying and fragmenting empire, realism has no room. Costumbrista writers of vignettes and every-day customs are too aware of this geopolitical divide to even attempt a narrative form that is being developed by French (and British) imperialist culture.

The critic José Montesinos accuses Mesonero Romanos of being morally 
reactionary. However, as Lukács himself repeatedly acknowledged, Balzac himself was a reactionary; he was ultimately a sympathizer of the AncienRégime landowning class-a class that was bound to disappear. Yet, as Lukács also demonstrated so lucidly, Balzac understood and represented the historical logic that led class struggle in capitalism. And as such, he wrote novels where the form and the content, to use an old dichotomy, represented this class history. Thus, it is not a matter of the author's personal morals but of his or her literary representation.

In this respect, Mesonero Romanos understood that the realist novel was not the answer to the geopolitical situation of postimperial Spain. Montesinos's accusation and discussion of Mesonero Romanos's understanding of the novel clarifies this apparent contradiction:

sus ideas de la novela [...] no eran del todo claras, y aun esos mismos pasajes atestiguan que la novela no le interesaba cosa mayor.[...] De las tres clases de novela de que Mesonero se ocupa, la fantástica y la histórica decayeron pronto de su momentáneo esplendor; sólo la de costumbres es viable, pero la que se cultiva y se lee muestra "el criminal empeño" con que "las emponzoñadas plumas de los Hugos y Dumas, Balzac, Sand y Soulié" se aplican a derrocar la moral. Y esto es todo lo que sabe decirnos Mesonero. Su artículo no trata de la novela propiamente, ni de las posibilidades artísticas del género, ni de novelas buenas o malas por sus cualidades intrínsecas; es un alegato, entre mil, si no contra la novela de costumbres, contra las costumbres que refleja la novela, y una incitación a que tales cosas no se hagan en España. La conciencia de la pobre vida española-pobre en un sentido, rica en otros-se expresa en forma bien castiza y bien aldeana en la orgullosa modestia con que Mesonero rechaza hasta la posibilidad de seguir las huellas de los novelistas franceses. (16-7, my emphasis)

In the Spanish case, the realist novel, as desired by Montesinos, could not be possible since industrialization and modernity, especially in its capital, 
Madrid, where costumbrismo eventually consolidated, were absent. Madrid only became an industrial center in the twentieth century-the only industrial bourgeoisie of the nineteenth century would flourish in Catalonia and the Basque Country. If in France the bourgeoisie lost its hegemonic hold after 1848 , in Spain this class attempted its first revolution in 1868. At that time Spain, and more centrally its capital, only had an incipient bourgeoisie of aristocratic origin (Cruz "Nobility and Revolution") and a middle class or petty bourgeoisie, which did not consolidate as a hegemonic class till much later. Jesús Cruz does not distinguish between bourgeoisie and middle class:

Burguesía o clase media en el contexto social de la España del siglo XIX se refiere al diverso conglomerado social situado entre la antigua nobleza y las clases trabajadoras. Un segmento que abarcaría desde los grandes capitalistas hasta la pequeña burguesía de modestos niveles de ingresos, aunque con estilos de vida pretenciosos. Incluimos a aquellos burgueses que se aristocratizaron, teniendo en cuenta que también se produjo un aburguesamiento de la vieja aristocracia. (El surgimiento 20)

However, in the following I will differentiate between both classes. As Carr notes, the middle class was "neither socially nor politically coherent," and, in this respect, could be differentiated from the bourgeoisie or "clases acomodadas:"

Spanish speech distinguished between the prosperous upper middle classes and the new aristocracy (las clases acomodadas) and the middle class proper (la clase media). This middle class was neither socially nor politically coherent. A whole section was dependent on miserably paid official posts. [...] One of the characteristic features of Spain has been the instability of this class in its lower regions: its history in the nineteenth and twentieth centuries was a calvary of keeping up appearances by means of 'double employment'. (287, my emphasis) 
Spanish costumbrismo does not capture the historical and modern novelty brought about by capitalism and a rising aristocratic bourgeoisie (and middle class) but rather the opposite. Costumbrismo chronicles the increasing fragmentation that the Spanish empire underwent in the first half of the nineteenth century after two consecutive French invasions, the Latin American wars of independence, new domestic unrest (Carlist wars), and the new British-controlled economic system of free trade, at a time when the Spanish empire still adhered to a mercantilist economic model within a mostly rural and only marginally industrialized economy (mostly through mines and sugar plantations in Cuba). As Susan Kirkpatrick established in the late 1970s,

[T] he reading public was interested in consuming new images of itself [costumbrismo] because it was aware of being in an era of transition: it was disturbed by the disruptive events and deep turmoil of the previous thirty years, excited by the winds of change and possibility, confused about the implications of change and about its own directions and goals. (31)

From a postimperial perspective, aware of the lack of a capitalist industrial development in Spain, as well as of its imperialist fragmentation, Spanish literature of manners seems the most "progressive" and "responsible" literature of the time. Costumbrismo's role of positioning the Spanish subject vis-à-vis capitalism and modernity is the same of that of European realism, although their means are the opposite. In Spain, unlike in France or Great Britain, the consolidation of a national hegemony and ideology does not lie on the representation of the new (class, economy, society, culture), but rather in the preservation of the old (class, economy, society, culture).

Only by holding on to postimperial fragmentation and loss was Spanish literature able to unfurl its ideological and cultural banners. Costumbrismo was engaged in creating a cultural and geopolitical space or location from which to counteract European modernity and, at the same time, rewrite a 
new genealogy of an older modernity, its modernity, that had originated with Spanish imperialism in the Renaissance. This discourse was neither nostalgic nor reactionary but geopolitically situated.

Costumbrismo's geopolitical situating act accounts for the absent "presence" of a colonial loss constituted as the central violent trauma of nineteenth century Spain. Only by studying colonial loss and Spain's indifference towards it, will we be able to understand the cultural and social struggle taking place in costumbrista literature and, more generally, in Spanish culture at that time.

John Sinnigen is so far one of the few critics who has studied the importance of colonialism in nineteenth-century Spanish literature along with Akiko Tsuchiya and William G. Acree Jr. (Empire's End) and Lisa Surwillo (Monsters by Trade). However, by and large, these works do not address colonial loss and, instead, concentrate on the colonies that were still a part of the Spanish empire during the rise of the naturalist novel. Sinnigen, for example, concentrates on Pérez Galdós in his Sexo y política. By doing so, he breaks new ground in the study of literature, but he does not fully explore the complexity of the phenomenon. He claims that:

En cada caso la aportación de la experiencia colonial es fundamental, pero su lugar en el texto es una función de lo que contribuye a la indagación de la cultura nacional. En cuanto a la resistencia colonial, apenas está presente aunque se trata de unas novelas escritas en el período de los veinte años que precedieron a la pérdida definitiva de las colonias de ultramar. (38)

By concentrating on "colonial contribution" and "resistance," Sinnigen overlooks the fact that colonial loss (most of Latin America) as much as colonial preservation (Cuba, Philippines, Puerto Rico, Guam) mark nineteenth-century Spanish literature and culture: both phenomena, loss and preservation, are part of a colonial continuum rather than distinct and separate processes. 
Now that I have resituated the geopolitical and cultural context of Spanish literature of manners under a new postimperial light, it is important to analyze the specific discursive forms, articulations, and shifts that costumbrismo effects from the 1820 s to the 1870 s. As I showed earlier, colonial loss appears only in a later period (1850s and 1860s), a time at which literature no longer had the power to articulate a geopolitical discourse except as a form of nationalist legitimation for the rising new bourgeoisie of the 1860s. It is at that point that costumbrismo becomes a nostalgic discourse able to represent for the first time, colonial loss, thus creating an unexplained representational void, a time lag of over 30 years.

\section{Mesonero Romanos}

Early Spanish literature of manners is a geopolitical discourse situated vis-à-vis European modernity; it attempts to create a location from which to contain the postimperial fragmentation triggered by North-European modernity. The fact that it does not develop into the realist novel, unlike its French and English counterparts, does not imply that it derives into mere nostalgic stereotyping. Therefore, it is important first to clear the critical negative discourse against costumbrismo perpetuated after Montesinos's seminal work.

The three accusations against this body of literature that Montesinos has helped to spread are the following: literature of manners does not represent the bourgeoisie and the middle class, just disappearing and anachronistic types; costumbrismo is essentially a nostalgic discourse; its tone or style is not narrative and historical but atemporal and moralistic. A close analysis of several texts by Mesonero Romanos allows us to counteract Montesinos's accusations and, at the same time, to unravel a very different scenario, in which the geopolitical situatedness of costumbrismo takes a very specific historical and literary shape.

Montesinos captures very well the contradiction of the incipient and yet 
non-consolidated bourgeoisie and middle class in nineteenth-century Spain, when he claims that such classes are not material for typification and, thus, for costumbrista literature. Here Montesinos advances a reductive understanding of literature of manners as a ("pintoresco") discourse that typifies non-modern characters:

\begin{abstract}
Desde Balzac, de ellas [bourgeoisie and middle class] han salido la mayoría de los protagonistas de la moderna novela, aunque también la aristocracia, nueva o vieja, le haya prestado numerosos caracteres. Hubiérase esperado algo parecido en España, pero [...] esas clases "no tienen costumbres", como dirá más tarde Alarcón; es decir, no tienen carácter; es decir no son pintorescas. En ellas se urden los más agudos dramas de la vida moderna, pero [...] no son pintorescas. Nuevamente [in costumbrista literatura] se hace coincidir el carácter con lo pintoresco, con el modo de vivir, con los usos. (117)
\end{abstract}

Yet Montesinos obfuscates the development of literature of mannersMesonero Romanos does represent the bourgeoisie and middle classes avoiding their reduction to mere types. As Susan Kirkpatrick points out: "costumbrismo was necessarily an ideological manifestation of the transition to modern, bourgeois society, expressing, among other things, the perspective and will of the class whose interest it served." (31) Furthermore, as Enrique Rubio Cremades clearly demonstrates, the middle class is the main object and subject of representation in Mesonero Romanos's early work:

Todo este conjunto de cuadros que configuran El Panorama [1835] y Las Escenas [1842] intenta abarcar todas las clases sociales, pero con especial incidencia a la llamada clase media pues según El Curioso Parlante [Mesonero Romanos's pen name], es el único conjunto social con personalidad propia ya que tanto la nobleza como el pueblo llano apenas ofrecen comportamientos desiguales en la civilizada Europa, de ahí que el autor afirme lo siguiente: "[...] que la clase media, en fin, por su extensión, variedad y distintas aplicaciones, es la 
que imprime a los pueblos su fisonomía particular, causando las diferencias que se observan en ellas." ("Introducción” 88)

Montesinos's second accusation is concerned with nostalgia. Through the analysis below of one of the articles by Mesonero Romanos ("Antes, ahora y después," 1837), I contend that most of his early costumbrista writings depict different contemporary events relating to the bourgeoisie and the middle classes without any traces of nostalgia. Furthermore, they pursue the opposite effect: they represent the uncanny, horrifying, and deadly effects provoked by the struggle of the bourgeoisie and middle class in their survival against an imported modernity.

Finally and in regards to the third accusation, Montesinos clearly states that: "[E]l costumbrismo tipifica casos y personas, mientras que la ficción los singulariza-aun allí donde les conserva un minimum de tipicidad para hacerlos recognoscibles [sic] como exponentes de algo, profesión, clase, etc." (34). In the case of Mesonero Romanos, this accusation is further complicated by the fact that most critics find his style morose and moralistic. In short, they accuse him of not engaging in historical narration and analysis. As a result of this dismissal (type-casting and morose style), critics were able to displace costumbrismo as a moralistic, stale style, out of history and, thus, a nonnarrative, a non-historical discourse frozen in time.

In contrast with that prevalent view, Rubio Cremades describes Mesonero Romanos as one of the first authors in Spain who understands the autonomy of literature. He is responsible for creating an autonomous space from which the public can, for the first time, have an aesthetic experience that is neither politically nor socially determined: "El Ilamado tono dulzón de Mesonero no es sino su equilibrio ante el suceso o el hecho analizado. El justo medio que le aparta de la vida política y motiva, afortunadamente, la fundación de un periódico ecléctico-Semanario Pintoresco Español-que, al igual que él, se 
apartará de toda connotación política." ("Introducción" 85-6) His Semanario pintoresco español became the most successful literary publication of its time, and as such, created a literary space in which literature of manners did not seek to typify reality. Rather, costumbrismo gave its first geopolitically-situated and yet aesthetically-autonomous view of contemporary society, in doing so, it provided that incipient bourgeoisie and middle class with the new optics they were looking for in the midst of postimperial fragmentation. As Michael larocci concludes when situating costumbrismo o cuadro de costumbres in the larger historical framework of romantic literature: "[T] he ostensibly objective focus of the cuadro de costumbres and the internal world of Romantic poetic expression, however, are in many ways two sides of the same coin. For with few exceptions, and despite Romantic myths to the contrary, the Romantic gaze whether turned inward to the subject or outward to the objects that surround it - registered a fundamentally bourgeois world view." (387, my emphasis)

The analysis of Mesonero Romanos's “Antes, ahora y después” (1837), can provide us a new way of understanding much of his early production. This article of manners is focused on a lineage of three women who embody the changes brought about by modernity. More specifically, the article uses the liminal status given to the female gender in modern literature in order to explain the changes undergone by the land-owning aristocracy in its transformation into the new high bourgeoisie of the beginning of the nineteenth century. Mesonero Romanos's original remark is quite literal and announces the bourgeois divide between public and private spaces: "Las mujeres, según la observación también exacta de otro autor crítico, son las que forman las costumbres, asi como los hombres hacen las leyes." (332) In this genealogy, the first female character, Doña Dorotea Ventosa, is introduced through a history that, first and foremost, is told not in simple chronological or historical terms, but in geopolitical ones (France/Spain/Arab countries): 
Doña Dorotea Ventosa [...] Nacida de padres nobles, y sesudamente originales, en aquellos tiempos en que los españoles no se habían aún traducido del francés [...she was first educated in a nun convent and then married off by her parents]. Pasó, pues, sin transición gradual, desde el dominio de la hermana superiora, al más positivo del marido superior. Porque es bien que se sepa que por entonces todos los maridos [españoles] lo eran, y tenían más punto de contacto con la arrogancia de los árabes, que con la acomodaticia cortesanía francesa. (334-35, my emphasis).

By the time Margarita, the third woman in this lineage, is introduced, she is represented as the embodiment of the new status and values of the bourgeoisie. Yet, her social embrace of modernity is depicted in a two-fold way. On the one hand, the author presents the successful continuity between both classes (land-owing aristocracy > bourgeoisie), and, on the other, he also represents the loss of social and moral values that makes this success an uncanny, violent, and traumatic experience. In the end, the successful continuity results in the death of Margarita. In short, the success of modernity and capitalism is celebrated thought its deadly consequences and transformed into a geopolitical Spanish failure:

Margarita vio entonces de lleno todo el horror de su situación, y tembló por ella misma y por sus hijos. Vio en Arturo [her son] una fiel continuación de la imprudencia de su esposo; vio en Carolina [daughter] un espejo fiel de su imprudencia; se vio ella misma víctima del ejemplo de su madre, modelo que dejaba a sus hijos; y no pudiendo resistir a esta terrible idea, sucumbió de allí a poco, dejándolos abandonados en el mar proceloso de la vida.

La sociedad, empero, recogió su herencia, la [sic] inspiró sus ideas, la [sic] comunicó sus ilusiones, y como había modelado a la abuela y a la madre, modeló también a los nietos, y éstos servirán de fiel continuación de aquel drama, y no hay que dudarlo, lo que fue antes, y lo que es ahora, eso mismo será después. (351, my emphasis). 
In this respect, the story of the female genealogy of this family captures literally what Lukács defines as the realism typical of Balzac's characters:

[E]ach participant in these conflicts of interest is, inseparably from his own purely personal interests, the representative of a certain class, but it is in these purely personal interests and indivisibly from them, that the social cause, the class basis, of these interests finds expression. (41)

In Mesonero Romanos's article on the genealogy of three female generations there is no type-casting nor nostalgia. Furthermore, this article is not an exception to his early production. Most of his costumbrista articles represent the (aristocratic) bourgeoisie and middle class in similar terms.

Yet, in the above article-perhaps the one that most successfully represents the transition from the aristocratic to the bourgeois order-the main character dies, as if to imply that the triumph of modernity leaves no location for the Spanish subject-in this case embodied by a liminal female character. In other words, modernity turns out to be deadly for the national Spanish subject.

Costumbrista narratives such as the one analyzed above, because of their geopolitical situatedness, emphasize the lack of continuity, the lack of a modern teleology for the Spanish (bourgeois) subject. There is then little or no difference in the acknowledgment of modernity's violence on display in costumbrista literature and its depiction in the European realist novel. As Lukács argues for Balzac's work: “[I]n almost every one of his novels Balzac depicts this capitalist development, the transformation of traditional handicrafts into modern capitalist production; he shows [...] how the old social formations and ideologies must yield before its triumphant onslaught." (49) However, Balzac's realist novels have a narrative subject that embodies and justifies, subjects, the teleology of modern capitalism. There is a hero at the end of his novels: the new (French) bourgeoisie. Yet, in the case of Spanish costumbrismo, the opposite is underscored: the lack of a teleology and of a successful position 
for the Spanish subject. In this respect, costumbrismo provides a very realistic account of modernity (and its history) in Spain.

By definition these accounts of manners cannot unfold in a teleological manner and thus cannot follow the narrative template, the form of the European realist novel. They are much closer to theater and drama-hence their recourse to the everyday setting and the vignette. Mesonero Romanos repeatedly emphasizes the dramatic nature of his narratives. It is not far-fetched to conclude that Spanish costumbrismo is closer to theater than to narrative realism. These scenarios of manners, with their lack of teleology and their high dramatic structure, do not build up to complex realist narratives. They remain small short sketches of an impossible scenario: the inability or incapability of the unstable Spanish middle and bourgeois classes to face European modernity. Instead of narrating in realist terms, costumbrismo performs in a dramatic fashion the impossibility of halting postimperialist fragmentation. Traumatic violence, rather than nostalgia, is the key discursive characteristic of these vignettes of manners. Yet their performative and dramatic representation is geopolitically realistic as the realist novel is in France or England.

At the same time, these dramatic everyday narratives are devoid of any clear political or moral tone, and thus can be read as existing autonomously from the rest of Spanish reality as literature or art-the irony present in some of them is not directly political or moral. Hence, they become the only site in culture in which history is recaptured, put together, held, as an autonomous literary or aesthetic event. Given that the bourgeoisie and middle class read Mesonero Romanos's literature of manners as an autonomous literary text, rather than as a referential historical or political tract, postimperialist crisis and decadence are aesthetically halted and contained in the Costumbrista text: it is transformed into an artistic reality with an aesthetic and literary value beyond postimperial history. As a result, a new literary and autonomous space, a realistic and geopolitically-situated space, emerges in which the middle class 
and the bourgeoisie can observe (read) themselves and thus can come to existence, against and in front of modernity. Literature of manners is probably the first cultural, aesthetic autonomous space where the Spanish bourgeoisie and middle class come to existence as such cultural subjects through aesthetic and literary self-recognition.

Yet, colonial loss is almost absent from Mesonero Romanos's costumbrismo. Only in an article from 1843-45 entitled "Contrastes. Tipos perdidos, tipos hallados," does a colonial subject appear for the first time: "El consejero de Castilla." The author comments: "[R]egresado luego a la Península, entraba por premio de sus dilatados servicios en el Consejo de las Indias o en el de las Órdenes, y de allí ascendía por último al Supremo de Castilla, a la Cámara, y al favor real" (485).

By the time the above reference to colonial loss appears in Mesonero Romanos's writing, a more powerful presence is constituted, not by the bourgeoisie and middle class, but, rather, by subaltern and provincial types, not identified by class but, rather, by region, origin, and/or gender. Only in the late 1830 s and early 1840 s does Mesonero Romanos, for the first time, record regional types that begin to resound with nostalgia. In this sense, articles such as "La posada o España en Madrid" (1839) or "La patrona de huéspedes" (1843) are clearly indicative of a new costumbrista sensibility. This proliferation of new types constitutes a new phase from the early costumbrista literature.

This new phase, which Montesinos interprets as the sole representative of costumbrismo's more complex history, is indeed typecasting and nostalgic. Yet, by the 1840s, literature of manners is not a new genre: it has been canonized and consolidated by one of the most successful publications of the nineteenth century: Los españoles pintados por si mismos (1843). It is also the decade when stereotyping physiologies appear: from the 1842 Fisiología del estudiante to the reprint of the 1856 Fisiología del beso, Montesinos counts 17 physiologies during this period (103-4). But in order to understand the costumbrista turn 
from the bourgeoisie and middle class to (gendered) subaltern-regional types and from dramatic realism to nostalgia, once again we must return to the issue of colonial loss. Only by analyzing this loss will we understand the full historical meaning of these cultural changes.

\section{Larra}

There is a partial exception in costumbrismo's indifference towards postimperial Spanish fragmentation and colonial loss: one of the late works of Mariano José de Larra. Larra actually makes direct reference to an existing colony-Cubarather than to an emancipated one, and in that sense, this is only a partial exception to the logic of postimperial indifference that I have been tracing here. Yet Larra's reference to the colonial space and its logic does explain the relationship between costumbrismo, postimperialist fragmentationindifference, and colonial loss.

Before analyzing Larra's articulation of colonial loss, it is important to emphasize that he also writes a type of literature of manners that represents the bourgeoisie and middle class and their situation vis-à-vis modernity. Similarly, to Mesonero Romanos, he writes accounts in which the bourgeoisie and middle class fall prey to modernity's effects. Perhaps the clearest example is his article "Costumbres. El casarse pronto y mal" (1832; Figaro 121-35). This early article foreshadows Mesonero Romanos's vignette analyzed above and, thus, its analysis helps to emphasize a continued obsession over the historical problem of modernity among all costumbrista writers and readers.

In Larra's "Costumbres. El casarse pronto y mal," a female character, once again, becomes the original protagonist of the first half of the article. She is a Spanish woman educated in the most conservative fashion who, nevertheless, marries a French man she meets during the Napoleonic invasion. She follows him to France where he dies, and several years later, she returns to Spain with a son. The contrasts in culture and politics between both nations confuse her 
and, as a result, she becomes a very disoriented mother without firm cultural or social convictions. Here, needless to say, the romantic ideal of the domestic woman, "void of intellect and full of emotion," makes the female protagonist the perfect target of modern life's complexities as she becomes "naturally" unable to face and solve them rationally-thus justifying the ideology of faulting woman for such geopolitical vulnerability.

In the second half of the story, the son becomes the protagonist. As a result of his confused Franco-Hispanic education, the son ends up in a romantic marriage that has no future. Eventually his wife commits adultery. In turn, the despair of the adulterous sight, pushes the son/husband to his own suicide as well as to the mother's sorrowful death-the adulterous wife also dies in her attempt to flee from her jealous husband. At the end, just before he dies, the son/husband addresses a letter to his mother. The letter is allegorical of Larra's position:

Madre mía: Dentro de media hora no existiré; cuidad de mis hijos, y si queréis hacerlos verdaderamente despreocupados empezad por instruirlos [...] Que aprendan en el ejemplo de su padre a respetar lo que es peligroso despreciar sin tener antes más sabiduría. Si no les podéis dar otra cosa mejor, no les quitéis una religión consoladora. (Fígaro 132, my emphasis)

This letter encompasses a new position that is neither modern nor traditional but blends both modern values ("despreocupación," “instrucción”) and traditional ones ("respetar" "religión consoladora"). At the same time, the son's suicide proves the impossibility of such an eclectic Spanish position. Similarly, to Mesonero Romanos's article, Larra's also emphasizes the dramatic impossibility of situating the Spanish subject vis-à-vis modernity. While both authors draw from the romantic trope of the hero's tragic death, they elaborate a situated position that points to a realist reformulation.

Larra's article of manners is even more significant given the personal 
circumstances of his suicide which was predicated on both his despair for Spanish society and his personal love life. Larra's sensitivity towards the effects of modernity in Spanish culture and literature, he did write an article dealing, not directly with colonial loss, but with a contemporaneous colonial situation, i.e. Cuba. However, this article does expose the importance and centrality of colonial loss in its full structural and historical complexity in costumbrismo in general.

As with other Spanish costumbrista writers, no article by Larra can be found where Spanish history is reevaluated through a reconsideration of colonial loss. However, towards the end of his life, once he had given up on the idea of progress, modernization, and nationalism, Larra began to make references to Spanish history. In "Horas de invierno" (Ideario 63-66), published on December $25^{\text {th }} 1836$, he gave up on the possibility of a national Spanish literature. As a result, postimpieral history made a comeback in Larra's writings. Noting the relation between imperial expansion and literary excellence, Larra reminisces about the "second Rome" (the Habsburg Spanish empire) and the early modern writers of the "Golden Age." At that point, colonial loss appears for the first time:

Volvieran, si posible fuese, nuestras banderas a tremolar sobre las torres de Amberes y las siete colinas de la ciudad espiritual, dominara de nuevo el pabellón español el golfo de México y las sierras de Arauco, y tornáramos los españoles a dar leyes, a hacer Papas, a componer comedias y a encontrar traductores. Con los Fernández de Córdoba, con los Espínolas, los Albas y los Toledos, tornaran los Lopes, los Ercillas y los Calderones. (Ideario 65)

Yet, this postimperial nostalgia took a more radical form, a few weeks before his suicide, in an article Larra dedicated an entire article to Cuba: "Fígaro a los redactores del Mundo" (1837; Obras 233-35). When Larra wrote the article, the situation in Cuba was unstable. Chaotic and idiosyncratic policies were applied 
by the Spanish government in the colony. While Cubans had been sworn by the progressive, liberal Spanish constitution of 1812 for the third time in August of 1836, a new conservative constitution replaced it in 1837. This change deprived Cuba of any representation in the Spanish Cortes and in the local governments (province and city). Instead, Cuba was to be governed directly by a "Capitán General."

Playing with the irony of these changes in the constitutional provisions about colonial rule and colonial representation, Larra identifies Cuba as the last region of the Spanish empire in which its postimperialist fragmentation and decadence can be contemplated with a "wholesome dignity"- the dignity of the liberal constitution of 1812 .

In the article, Larra includes a fictional letter sent by a Cuban reader. The Cuban man's self-description is telling of Larra's own situation near suicide: "Soy hombre concienzudo y honrado; no extrañe usted este principio extravagante, ni me llame loco todavía; a causa de esas dos cualidades me ando solo por el mundo, por no encontrar con quien hacer pareja. Soy además habanero; esto no es tan raro [...]" (Obras 233, my emphasis). As the letter progresses, the protagonist's personal loneliness stops being simply a personal or ethical issue and becomes political. As a colonial subject, he becomes a reminder of the Spanish empire before colonial loss. More specifically, Larra conveys the idea that the Cuban subject, because of his renewed colonial condition, now void of legal and political representation, becomes a reminder of an earlier liberal empire void of colonial loss:

Ya se acordará usted, señor Fígaro, que en agosto pasado se juró la Constitución de 1812 en esta monarquía, y de que por tercera vez dijimos todos: 'Constitución o muerte'. Recuerdo este hecho porque como casi nadie la ha observado, pudiera habérsele olvidado a usted. Yo soy constitucional, si los hay." (Obras 233, my emphasis) 
This colonial record of an imperialist Spain capable of articulating a liberal response to the threat of colonial loss refers to a key moment in early nineteenth-century history, in which Spain's approach to modernity and its geopolitical position were aligned: in 1812, Spain became the cradle of modern liberalism through the proclamation of an imperial Constitution that envisioned colonial subjects as national citizens. Thus, Larra deploys a colonial testimony in order to return to a geopolitical moment that seems to have been erased from public memory in Spain. Such remembrance actually requires the recollection of imperial loss, even if elliptically.

The Cuban subject then proceeds to relate his personal political situation as "outlaw" when, heading to Madrid from a trip to Paris, he attempts to cross the French border with Spain. At that point, he finds out that "returning home" is not possible: he has become an outlaw because of his colonial, Cuban condition:

Pero es el caso, señor Fígaro, que en el día me encuentro con que en La Habana no sólo no se ha jurado la Constitución [of 1812], sino que no se ha debido jurar; que el gobierno, a quien yo tanto respeto, ha mandado que no se jure, y que los habitantes de la isla de Cuba, que la han jurado, son rebeldes; que parece que la Constitución no es género ultramarino, ni menos un bien absoluto, sino relativo; en una palabra, que es como un sombrero que no viene bien más que a la cabeza para la cual ha sido hecho, y por tanto sólo en la Península puede convenir; que es como si dijéramos: "tal para cual." (Obras 233, my emphasis)

As the writer of the letter clearly states, the very same logic of postimperial Spanish politics both seeks to retain Cuba while curtailing its constitutional rights, thus turning its allegiance to the earlier constitutional rights into a form of rebellion ("rebeldes"). In other words, the confrontation between liberal modernity and traditional imperialist Spain generates the logic that explains imperial fragmentation and colonial loss. That is why the Cuban writer refers to 
the constitution of 1812 and its significance back in that year, when modernity and Spanish liberal imperialism had been apparently aligned. In other words, the colonial subject, and his understanding of the logic of colonial loss (he now represents a "rebellious" colony bound to seek independence), explains Spanish history in a way that Larra finds exemplary ("concienzudo y honrado," "solo") and with which he identifies.

This colonial exemplarity, as a reminder of imperial loss, is reaffirmed by Larra only a few weeks away from committing suicide. Larra terms this colonial exemplarity "conciencia" in the double sense that the word has in Spanish: conscience and consciousness. Furthermore, the colonial position is the only one in which such "conciencia" still exists, that is, a consciousness that can reestablish a balance between modernity and Spanish imperialism:

Sáqueme usted, señor Fígaro, cuanto antes de estas dudas; cuente que le deberé más que la vida, pues le deberé el honor y mi salvación, y mire que no se pierda mi conciencia, siquiera porque tengo para mí que es la única que ha quedado en todos los dominios que tan felizmente rige y gobierna el señor Calatrava, q.D.g. (como oro en paño), y que tan anchamente recauda el señor Mendizabal (q.D.h.), si algo le queda por haber. Suyo afectísimo. El Habanero. (Obras 235, my emphasis)

In other words, while postimperial forgetfulness of colonial loss had been necessary to create a new geopolitically situated literary location-Larra's costumbrismo-, in the last moment, before he takes his own life, Larra alludes to the memory of an actual colony, Cuba, in order to recreate an earlier political solution that could preempt Spanish postimperialist fragmentation. In other words, Cuba is the only place-the colony-from which he can still imagine a space that is able to escape postimperialist fragmentation through constitutional representation, even if that mode contradictorily announces its "rebellious" future, and the threat of permanent fragmentation through 
independence. Before Larra himself falls prey to national fragmentation, he has to imagine himself as colonial, as Cuban, to resist and to imagine a space that is the location par excellence of costumbrista literature. The colonial space is the only location, the only true "everyday location," that in last instance can resist imperialist fragmentation and face modernity at the same time. Only a Cuban Larra can serve to nationally suture a fragmented Spain while also announcing its future full fragmentation.

As Lucy D. Harney explains, the difference between Mesonero and Larra, in their nationalist agendas, is clear:

Mesonero's rhetorical elimination of all but the middle class in his ideation of national identity results in a reductive social optimism. This as against Larra's globalizing social pessimism which emerges as he struggles to function as a writer and social thinker within a literary medium whose primary function reveals itself increasingly to be the propagandistic organ of utopic bourgeois positivism. (163)

But this conclusion can be expanded through a postimperial analysis. Mesonero Romanos exemplifies costumbrismo's initial success in holding together, halting, postimperial fragmentation and disavowing colonial loss for the Spanish middle and bourgeois classes in a realist fashion. Larra, instead, represents costumbrismo's realist and dramatic avowal of its ultimate failure in creating a space that would allow the Spanish empire to halt fragmentation and colonial loss while facing modernity. Larra does so by positioning himself and his writing on the colonial field and, with the memory of the failed promise of a transatlantic constitutional modernity, he proceeds to kill himself as a way to inscribe in his own body Spain's deadly postimperial condition of despair.

As Mary L. Coffey has analyzed, even in the successful Los españoles (1843), the colonial presence is limited to the portrait of "el indiano" (the Spaniard who returns from the colonies after trying his fortune there). The goal of this 
representation, however, is "rechazar la experiencia colonial y separarla de la nueva definición de España como una nación” (Coffey, “El costumbrismo” 298).

\section{Estébanez Calderón: Nostalgia and its Subaltern Colonial Others}

Postimperial fragmentation and indifference towards colonial loss mark the beginnings of costumbrismo during the 1830s and 1840s. This literary corpus is both realist and centered on the incipient bourgeoisie and middle classes. It also is articulated alongside libidinal structures such as trauma and disavowal, which ultimately revert to colonial loss: the ultimate unacknowledged horizon of imperialist fragmentation. Nostalgia does not make its appearance in costumbrismo until the mid-1840s. Nostalgia is first encoded when Spanish literature of manners finally becomes a successful and mass-consumed cultural phenomenon with the publication of Los españoles pintados por si mismos (1843, Criado Becerro; henceforth Los españoles) and with the emergence of a subgenre devoted to physiologies. At the same time, the irruption of nostalgia must be considered as revelatory of a larger social and cultural shift in Spain.

Costumbrista literature's new shift towards nostalgia is accompanied by a representational change. This literature no longer focuses on the bourgeoisie and the middle class, but rather on subaltern and low-class types. These "types" are truly typifications, as denounced by Montesinos, and respond to representations of social groups and subgroups that are disappearing as a result of modernity's irruption. Later on, as I will discuss below, stereotyping expands to three other areas: women, Spanish peripheral regions, and Latin America. Yet it is important to underscore that the shift from representations of the bourgeoisie and the middle class to other classes and groups, nevertheless, means a continuity in terms of its reading public: the readers continue to be constituted mainly by the middle class and the bourgeoisie at large. The bourgeoisie and middle classes shift their reading tastes so that they move from reading about itself (early costumbrismo from the 1830s through the early 
1840 s) to reading about the other (late costumbrismo from the early1840s through the 1870s). As a result, the field of typification (otherness) progressively expands, so that it eventually includes not only subaltern classes but also Spanish regions, women, and even Latin America. Thus, finally costumbrismo confronts colonial loss through a nostalgic discourse that places the colonial other within a catalogue of Spanish types.

The representation of peripheral regions was already present at the inception of costumbrismo. One of its main practitioners, Estébanez Calderón, wrote specifically about Andalusia. Yet, fully aware of the exoticist and orientalist position-a position of otherness-that Andalusia occupies in north European and modern portrayals of Spain, he also claims for his region a position similar to that of Spain. Thus, there is no contradiction between the representation of Spain-through the bourgeoisie and the middle class —and Andalusia-through rural classes. In this respect, Estébanez Calderón's literature does not seek to "other" Andalusia through nostalgia and typification:

Así españoles como extranjeros, saben el remoquete con que son señalados los andaluces [they are reputed to be very exaggerated...]. Fuera agraviar a cuatro grandes provincias que valen otros tantos imperios, suponerles en su calidad y condición algo tan rahez y de baja ley que pueda trocarse con el embuste y confundirse con la gratuita mentira. Esto siempre revelará algún defecto en el carácter, cierta falta en el corazón, siendo así que, en contraste con todas las demás de España, no hay ninguna que sobre la Andalucía presente mayor número de héroes, de hombres valientes, y todos saben que la cualidad más contraria al valor es la mentira. (30)

Therefore, even in relation to the Spanish area most overdetermined by orientalism, i.e. Andalusia, costumbrismo shows a high level of geopolitical consciousness and criticism. 


\section{Los españoles pintados por sí mismos}

However, when regionalist types are introduced in 1843 by Los españoles, they are othered through typification. In the introduction, the editors claim that: "ofrecemos a la sensatez de nuestros compatriotas una colección de alimañas, tipos degenerados que nos quedan de nuestra bastardeada originalidad" (Criado Becerro vi). Thus, this time, regionalism along with subalternity become elements of a Spanish reality that the reading middle and bourgeois classes are eager to see as they disappear through a discourse of nostalgia. When comparing Los españoles with its European counterparts, José Manuel Losada concludes:

The relationship among various types described is striking, especially in the English and French collections. The Spanish case is different. Certainly, a number of social types are repeated: the public writer, the literary novice, the poet, or the convict. Nevertheless, the objective of Los españoles pintados por si mismos is not to produce a systematic sample of all the social types. On the contrary, it offers an abundance of the simpler types and physiognomies that could only be found in Spain: those whom social upheavals had reduced to types on the path to extinction. (344)

Through nostalgia, the Other is acknowledged as "us" and, then, othered through a discourse of modernity that makes it old and, thus, historically bound to disappear. Or to use a more Foucauldian phrasing, the bourgeoisie and middle class are keen to apply to other subaltern groups the violence that modernity had originally exerted on them. As a result, the shift to nostalgia is the first indicator that the Spanish bourgeoisie and middle class think of themselves as modern and, thus, are willing to contemplate postimperialist fragmentation as a cultural spectacle that can be enjoyed as such, as the spectacle of the Other-a spectacle of violence no longer affecting them.

Historically, the 1840 s, and especially the 1850 s, saw the arrival of French 
capital investment and technocrats, as well as an acceptance of French (and British) culture as the new cultural referent by the Spanish bourgeoisie and the middle classes. As Jesús Cruz summarizes in relation to the Spanish bourgeoisie:

A lo largo del siglo XIX, las publicaciones periódicas españolas de moda y cultura de la moda en general continuaron siguiendo el modelo francés $\mathrm{y}$, en menor medida, el inglés. Los periodistas, los consumidores, y el mundo de la confección emulaban con fascinación los dictados de la moda de París. [...] El conde de Ségur escribió en 1818 que la moda de París era el único soberano cuyas órdenes, caprichos y fantasías nunca fueron cuestionados, incluso por los más obstinados. (El surgimiento 191)

By the 1850s and 1860s, the new Spanish bourgeoisie and the middle classes no longer contemplated postimperialist fragmentation and an imported modernity as their problem. Literally, they represented modernity's violence as a problem of the "Other." The Spanish bourgeoisie - and the middle class in so far as it identified with the former- became modern and their deployment of nostalgia was designed to celebrate the disappearance of non-modern Spanish reality, including Spain's fraught postimperialist condition.

Margarita Ucelay Da Cal chronicles the different books that costumbrismo yielded from the 1850s through the 1880s. Her study still remains more exhaustive than the more recent by María Angeles Ayala (Las colecciones), although not as analytical. A quick glance at Ucelay Da Cal's catalogue permits to see the expansion of otherness to peripheral regions, women, and Latin America: El álbum del bello sexo o las mujeres pintadas por sí mismas (1843), Doce españoles de brocha gorda (1846), Los valencianos pintados por sí mismos (1859), Las españolas pintadas por los españoles (1871-72), Los españoles de ogaño (1872), Las habaneras pintadas por sí mismas (1847), Los cubanos pintados por sí mismos (1852), Los mexicanos pintados por sí mismos (1854-55), Las mujeres españolas, portuguesas y americanas (1872-76), Los hombres españoles, 
americanos y lusitanos pintados por sí mismos (1880-82), Las mujeres españolas, americanas y lusitanas pintadas por sí mismas (1880-82). Most, but not all, of the above collections were published by Spanish authors in Spain, and so contain a transatlantic diversity of participants and viewpoints that demands further analysis (Coffey "El imperio pintado"). Yet, the impulse towards the expansion of the category of otherness is clear.

This progression in the inclusion of the Other (women, regions, Latin America) goes hand in hand with a new and nostalgic representation, not of social classes (professions, etc.), but rather of folkloric and national types (and of women, as domesticity becomes a space of otherness and other regions/colonies are also feminized). Da Cal reflects on Las mujeres españolas, portuguesas y americanas (1872-76) and concludes that:

Aunque este libro pertenece sin ningún género de duda a la corriente que venimos estudiando, marca dentro de ella un punto de evolución de gran interés: el tránsito de la actitud pintoresquista del costumbrismo, en el tratamiento de los tipos populares, a la visión folklórica de la vida tradicional. Por eso, a pesar de que en su estructura externa obedece a las normas de las colecciones costumbristas de tipos en colaboración, en lo esencial difiere de ellas. No se puede decir con justicia, que en su espíritu y tendencia generales esta galería pertenezca al género, si bien tiene adherencias todavía muy claras. Para empezar, desaparece aquí completamente la visión de los tipos y su clasificación con arreglo a profesiones, clases, oficios, o trazos psicológicos generales, y en su lugar nos ofrece representantes de zonas geográficas peninsulares de España y de Portugal, así como de las naciones de América.

Al hacerlo así desaparece, como es natural, la posibilidad de caracterización de la especie dentro del conjunto de la sociedad a que pertenece, para darnos en su lugar una serie de monografías más o menos eruditas. En ellas por un proceso bien explicable, se busca definir a la mujer de cada una de las tierras en cuestión por medio del tipo campesino [...] (202, my emphasis) 
When costumbrismo became an expanding nostalgic spectacle portraying the violent disappearance of non-modern Spanish types (regionalist and subaltern types), precisely at that point, (post)colonial Latin America, disavowed until that point from costumbrista literature, reemerges. Ironically enough, colonial loss reappears in the 1870s, at the very end of the period dominated by costumbrismo. Colonial Cuba had begun to be represented since the 1850s. Despite its inclusion, Latin America was presented as an extension of regional Spain, and, mostly as feminized and subaltern. In short, the re-representation of colonial loss is not articulated alongside postimperialist lines-as loss and fragmentation-but along new nationalist lines, whereby different parts of Latin America are acknowledged as independent nations embodied by their subaltern and rural women. Mary L. Coffey has analyzed in detail the differences between the representations of the independent republics, such as Mexico, and contemporary colonies such as Cuba in several costumbrista collections ("El imperio pintado").

We must conclude that, as the Spanish bourgeoisie and the middle class aligned themselves with modernity, these classes also brought about a new discourse: nationalism. Through this new discourse, Spain ceased to portray itself as an empire in decadence and attempted to refashion itself as a new nation, with a cultural and political essence-precisely the essence that subaltern Spanish and Latin American women as well as Spanish regional types can represent from their peripheral and othered positions. Alda Blanco has called this new ideological reconfiguration "imperial nation" (Cultura y conciencia imperial). Women, Spain's different regions, as well as Latin American nations/colonies, constituted a single continuum of otherness for the new Spanish bourgeoisie and middle classes that sought to refashion postimperialist fragmentation through nationalism.

When costumbrismo was able to finally contain and other any form of postimperialist fragmentation through the new modern discourse of 
nationalism, it faded away as a marginal discourse that no longer was able to represent Spain's new bourgeois, modern, national reality. It appeared to have already fulfilled its function. It was at that point that the naturalist novel emerged with a vigor that still surprises the critics to this day. Although María de los Ángeles Ayala postulates a second moment of popularity and increased publications for costumbrismo between the year 1870 and 1885 ("Las colecciones costumbristas" 16), it appears more likely that expansion of the publishing industry accounts for the growth of all literary genres, including literature of manners, which nevertheless loses its central hegemonic position in the Restoration.

\section{The Atlantic Symbolic}

The masterpiece of naturalist literature, Galdós's Fortunata y Jacinta (1887), also resorts to a colonial logic. Ultimately Spanish literature and culture always revert to the (post)colonial-imperial field of the Hispanic Atlantic as its symbolic order (one that encompasses the entire (post)colonial-imperial field, including non-Atlantic areas such as the Philippines). That is, Spanish nationalist culture finds in the Hispanic Atlantic the order against which it refashions itself as national. At the same time, the Hispanic Atlantic always contains a traumatic kernel, a noise-such as Galdós's subaltern character Fortunata with her Manila shawl-that exceeds this symbolic order and organizes it (Gabilondo "Galdós, Etxeita, Rizal"), so that Spanish culture cannot but continually return to the Hispanic Atlantic to redefine itself unsuccessfully, first, as indifferent postempire (costumbrismo) and, then, as nation (late costumbrismo and naturalism). This lack of success points to the imaginary nature of a national Spain (or Spain as nation) and to the symbolic nature of the Atlantic-now dominated by Britain.

In 1898, Spain finally lost the remains of its imperial past. The complete loss of its colonies underscored a cultural and political reality that the naturalist 
novel and the culture of the Restoration could no longer contain within an imaginary nationalist identity: the full fragmentation and dismantling of the Spanish empire. Spanish culture was no longer able to other its own postimperialist fragmentation (as costumbrista type, regional, female, LatinAmerican, or otherwise) and, by default, fashions itself as nation. Consequently, the Generation of 98 turned to metaphysical reformulations of Spanish otherness - the empty Castile and Don Quixote - as a way to hold on to an imaginary national identity for the postempire. Yet these forms of otherness ultimately do not escape the Hispanic Atlantic symbolic order that regulates them: after all, Castile nostalgically stands for the empty center of the longgone Spanish/Habsburg empire of the Renaissance. Postimperialist loss can no longer be contained as an imaginary reality through the deployment of a discourse of national identity and its others. Colonial loss becomes real and traumatic: the Disaster of 1898 cannot be imagined and symbolized by the national and naturalist culture of the Restoration. Consequently, the Generation of 98 becomes entrusted with the task of reorganizing a new postimperial national discourse that finds its Others in a history that disavows colonial loss but avows its long-gone imperialist dimension: Castile as the empty center of a long-gone Spanish imperialist project, that is, as a sublimated form of imperialism and/or as the imperial sublime. Hence, the traumatic nature of 1898 and its marked contrast with the postimperial indifference at the beginning of the century.

\section{Global/Postmodern Nostalgia and a Hispanic Return to Modernity} Reflecting on postmodern culture and its avid tendency to represent nostalgia, Jameson concludes that its affective structure is the key element that points to the end of history and, thus, to our inability to access our own historicity in globalization (postmodernism): 
Yet this mesmerizing new aesthetic mode [nostalgia] itself emerged as an elaborate symptom of the waning of our historicity, or our lived possibility of experiencing history in some active way. It cannot therefore be said to produce this strange occultation of the present by its own formal power, but rather merely to demonstrate, through these inner contradictions, the enormity of a situation in which we seem increasingly incapable of fashioning representations of our own current experience. (21)

As Jameson clearly states, the "waning of our historicity" first and foremost is a process that points to our inability to fashion "representations of our own current experience." At the same time, this inability to fashion the global present ultimately brings about an inability to represent the past. Jameson concludes that we are placed in "a new and original historical situation in which we are condemned to seek History by way of our pop images and simulacra of that history, which itself remains forever out of reach." (25) Jameson relates this waning of historicity to the fragmentariness that pervades postmodern (global) culture: "If, indeed, the subject has lost its capacity [...] to organize its past and future into coherent experience, it becomes difficult enough to see how the cultural productions of such a subject could result in anything but 'heaps of fragments' and in a practice of the randomly heterogeneous and fragmentary and the aleatory." (25) From a North-American perspective, it would seem that global/postmodern nostalgia, in its "new" and "unprecedented" reorganization of culture, through fragmentation, blocks any access to history and modernity. Yet, if the analysis of nostalgia and costumbrista literature in postimperial Spain is applied to Jameson's global dilemma, a very different reading of the "newness" of global/postmodernist nostalgia can be elicited.

First of all, nostalgia and fragmentariness simply constitute a reorganization of cultural representation effected by a new emergent class that pays farewell to forms of modernity that no longer are necessary for its cultural hegemony. In the case of nineteenth-century Spain, this reorganization is carried out by a new 
bourgeois (and middle) class and its nationalist refashioning of postimperialist fragmentation. In the case of a globalized North America and, more generally, of the Global North, the process is the opposite: a new elite is refashioning itself in imperialist/global terms and thus its local nationalist markers-its regional North American national traces-are othered and ultimately shed away. This othering process explains North America's nostalgic fascination with the 50s, i.e. its foundational, national origin as global superpower. Thus, global/postmodern nostalgia has little to do with not having access to both history and modernity, and much to do with a new reorganization of history and reality along the geopolitical emergence of a new (neoliberal) global class. This new reorganization is neither unthinkable nor non-accessible if a nonpostmodern position, such as the Atlantic Hispanic, is adopted. Homi Bhabha made a similar case for the postcolonial world (The Location of Culture).

If Spain (along with Portugal) was the first modern empire suffering fragmentation and decadence in the nineteenth century, then a genealogy of nostalgia would require to downplay the novelty of globalization/ postmodernism and, instead, to underscore the relationship between nostalgia and the emergence of new global geopolitical realities. Global/postmodern nostalgia, just as Spanish nostalgia did in the nineteenth century, points to the fragmentation and decay of North American hegemony and to the rise of a new postnational, neoliberal, and global elite who no longer shows clear allegiances with any nationalist agenda, be it North American or Spanish. In this context, nineteenth-century Spanish costumbrista nostalgia can be rescued as the first massive elaboration of nostalgia in modernity. Nineteenth-century Spain nostalgically mourns the loss of its version of modernity, which emerged with its constitution as a modern empire in the sixteenth century. This is not the north European romantic nostalgia for the Ancien Régime. Nineteenth-century postimperial Spanish nostalgia is, in strict historical and literal terms, postmodern nostalgia: the nostalgia that emerged after imperialist Spanish modernity 
was lost. Exploring its epochal consciousness allows us to question the almost unthinkable difference between modernity and postmodernity/globalization, a boundary that becomes blurred as a new historical continuity emerges in the Hispanic Atlantic.

\section{Works Cited}

Ayala, María Ángeles. Las colecciones costumbristas (1870-1885). Universidad de Alicante, 1992.

-. "Las colecciones costumbristas en la segunda mitad del siglo XIX: entre la nostalgia y la crítica." Insula: Revista de letras y ciencias humanas, no. 637, 2000, pp. 16-18.

Bhabha, Homi. The Location of Culture. Routledge, 1994.

Blanco, Alda. Cultura y conciencia imperial en la España del siglo XIX. Publicacions de la Universitat de València, 2012,

Carr, Raymond. Spain 1808-1975. Oxford University Press, 1982.

Coffey, Mary L. "El costumbrismo decimonónico y la ansiedad colonial, o cómo representar la pérdida de un imperio." Actas del XVI Congreso de la Asociación Internacional de Hispanistas: Nuevos caminos del hispanismo. Vol. 2. Eds. Pierre Civil and Françoise Crémoux. Iberoamericana Vervuert, 2010, pp. 296-302.

-. "El imperio pintado por sí mismo: el costumbrismo transatlántico," Hispanismos del mundo. Diálogos y dabates en (y desde) el Sur. Digital Anex. Section V. Ed. Leonardo Funes. Miño y Dávila, 2016, pp. 139-50.

Criado Becerro, Agustín ed. Los españoles pintados por sí mismos. Madrid: Dossat, 1992.

Cruz, Jesús. "Nobility and Revolution: Social Origins of the Political Elite in Liberal Spain, 1800 to 1853." Comparative Studies in Society and History, vol. 36, 1994, pp. 97-121.

-. El surgimiento de la cultura burguesa: Personas, hogares y ciudades en la España del siglo XIX. Siglo XXI, 2014.

Estébanez Calderón, Serafín. Escenas andaluzas. Espasa-Calpe Argentina, 1941.

Freud, Sigmund. "Mourning and Melancholia." The Standard Edition of the Complete Psychological Works of Sigmund Freud. Ed. James Strachey, vol. XIV, The Hogarth Press, 1953-74, pp. 243-58. 
Gabilondo, Joseba. “Galdós, Etxeita, Rizal - Madrid, Mundaka, Manila: On Colonial Disavowal and (Post)Imperial Articulations of the Hispanic Pacific-Atlantic." 452F: Revista de Teoría de la Literatura y Literatura Comparada, vol. 9, 2013, pp. 13-43.

Gilroy, Paul. The Black Atlantic: Modernity and Double Consciousness. MA: Harvard UP, 1993.

Harney, Lucy D. "Audience and Representation in Costumbrismo." Torre: Revista de la Universidad de Puerto Rico, vol. 7, no. 24, 2002, pp. 145-66.

Iarocci, Michael. "Romantic Prose, Journalism, and Costumbrismo." The Cambridge History of Spanish Literature. David T Gies, ed. Cambridge UP, 2004, pp. 381-91.

Jameson, Fredric. Postmodernism or, the Cultural Logic of Late Capitalism. Durham: Duke UP, 1991.

Kirkpatrick, Susan. "The Ideology of Costumbrismo." Ideologies and Literature: A Journal of Hispanic and Luso-Brazilian Studies, vol 2, no. 7, 1978, pp. 28-44.

Kristeva, Julia. Powers of Horror: An Essay on Abjection. Trans. Leon S. Roudiez. Columbia UP, 1982.

Lacan, Jacques. “La signification du Phallus.” Écrits. Paris: Seuil, 1966, pp. 685-95.

Larra, Mariano José. Fígaro: Collección de artículos dramáticos, literarios, políticos y de costumbres. Ed. Alejandro Pérez Vidal. Crítica, 1997.

—. Ideario español. Linkgua ediciones, 2019.

-. Obras completas de Fígaro (Don Mariano José de Larra), vol. 3, Imprenta de Yenes, 1843.

Lukács, George. Studies in European Realism. Hillway, 1950.

Mesonero Romanos, Ramón de. Escenas y tipos matritenses. Ed. Enrique Rubio Cremades, Cátedra, 1993.

Montesinos, José F. Costumbrismo y novela. Ensayo sobre el redescubrimiento de la realidad española. Castalia, 1960.

Montgomery, C. M. Early costumbrista writers in Spain, 1750-1830. University of Pennsylvania, 1931.

Rubio Cremades, Enrique. "Introducción." Escenas y tipos matritenseses, de Ramón de Mesonero Romanos, 1993, pp. 9-118. 
—. "Costumbrismo: Definición, cronología y su relación con la novela." Siglo Diecinueve, vol. 1, 1995, pp. 7-25.

Sinnigen, John. Sexo y política: lecturas Galdosianas. Ediciones de la Torre, 1996.

Suárez Fernández, Luis. Historia General de España y América. Vol. 15. Reformismo y progreso en América (1840-1905). Rialp, 1989.

Surwillo, Lisa. Monsters by Trade. Slave Traffickers in Modern Spanish Literature and Culture. Stanford University Press, 2014.

Tsuchiya, Akiko and William G. Acree Jr. eds. Empire's End. Transnational Connections in the Hispanic World. Vanderbilt University Press, 2016.

Ucelay Da Cal, Margarita. Los españoles pintados por sí mismos (1843-44). Colegio de México, 1951. 